\title{
ANALISIS FAKTOR IMPLEMENTASI MANAJEMEN K3 TERHADAP KINERJA BIAYA PELAKSANAAN PROYEK KONSTRUKSI
}

\author{
Yaser Arafat ${ }^{1}$ dan Retna Hapsari Kartadipura ${ }^{\mathbf{2}}$ \\ ${ }^{1}$ Program Studi Magister Teknik Sipil Universitas Lambung Mangkurat \\ ${ }^{2}$ Faculty of Engineering, Lambung Mangkurat University
}

\begin{abstract}
ABSTRAK
Tujuan penelitian ini adalah 1) untuk menganalisa implementasi faktor K3 yang mempengaruhi kinerja biaya pelaksanaan proyek konstruksi, dan seberapa besar tingkat pengaruhnya. 2) untuk menganalisa bagaimana hubungan faktor-faktor K3 terhadap kinerja biaya pelaksanaan konstruksi. Proses rancangan penelitiannya dimulai dengan pengumpulan data-data primer melalui kuesioner yaitu data pengaruh implementasi SMK3 terhadap kinerja biaya proyek. Populasi utama yang menjadi objek penelitian adalah pihak perusahaan atau kontraktor yang berdomisili di wilayah Kalimantan Selatan, dengan jumlah sampel 36 perusahaan kontraktor. Instrumen yang digunakan adalah kuesioner tertutup. Metode analisis data dari penelitian ini menggunakan analisis statistik deskriptif dan analisis korelasi. Dari hasil penelitian maka diperoleh hasil 1) Implementasi faktor $K 3$ dalam penelitian ini terbukti mempengaruhi kinerja biaya pelaksanaan proyek konstruksi. Membuat perencanaan K3 yang terkordinasi merupakan indikator yang paling berpengaruh pada faktor perencanaan dengan indeks 4,00. Implementasi faktor K3 yang paling berpengaruh terhadap kinerja biaya adalah faktor perencanaan $K 3(3,62)$, kemudian faktor pelaksanaan $K 3$ $(3,55)$ dan yang terakhir adalah faktor evaluasi K3 (3,34). 2) Faktor-faktor implementasi K3 yang memiliki korelasi kuat terhadap kinerja biaya asuransi adalah faktor memantau pemenuhan peraturan perundangundangan dan persyaratan lainnya berkaitan dengan penerapan $K 3$ di tempat kerja. Tinjauan ulang kontrak merupakan indikator yang berhubungan kuat dengan biaya proyek dalam hal peralatan keamanan. Indikator pemantauan efektifitas pengendalian merupakan indikator yang memiliki korelasi kuat dengan fasilitas kesehatan. Indikator evaluasi penerapan sistem manajemen $K 3$ perusahaan merupakan indikator yang berkorelasi sangat kuat terhadap biaya pengawasan terhadap penerapan safety. Indikator yang memiliki korelasi kuat terhadap biaya-biaya kecelakaan yang terjadi adalah indikator evaluasi keefektifan pengendalian operasi K3. Indikator pelaksanaan audit sistem manajemen K3 merupakan indikator yang berkorelasi sangat kuat terhadap biaya lain yang berkaitan dengan sistem keamanan kerja.
\end{abstract}

Kata Kunci: manajemen K3, konstruksi dan kinerja biaya

\section{PENDAHULUAN}

Dewasa ini sektor konstruksi sudah sangat berkembang pesat baik dari segi fisik maupun dari sisi biayanya. Dalam prakteknya suatu proyek konstruksi memiliki keterbatasan sumber daya baik sumber daya manusianya maupun sumber daya biaya. Kompleksitas pada perkembangan proyek konstruksi ini pada akhirnya membutuhkan suatu manajemen proyek yang efisien.

Manajemen proyek yang efisien berkaitan dengan alokasi sumber daya biaya yang tepat dan merupakan aspek yang menjadi

Correspondence: Yaser Arafat

Email : yaser_2482@yahoo.co.id perhatian para pelaksana proyek konstruksi.

Salah satu aspek biaya dalam proyek konstruksi adalah biaya Keselamatan dan Kesehatan Kerja yang dikenal dengan K3. K3 merupakan elemen penting dalam suatu pelaksanaan proyek konstruksi. Pada dasarnya penerapan K3 adalah suatu upaya agar faktor kecelakaan dapat dikurangi bahkan dihindari. Caranya yaitu dengan menghilangkan resiko yang akan terjadi sehingga dapat mencapai target kerja sebuah proyek. Data dari Kementerian Ketenagakerjaan menunjukkan bahwa angka kecelakaan kerja yang dialami pekerja konstruksi relatif tinggi yaitu 31,9\% (Kurniawan, 2015).

Adanya biaya yang dialokasikan oleh pelaksana proyek konstruksi pada K3 maka para pelaksana proyek konstruksi dapat 


\section{ANALISIS FAKTOR IMPLEMENTASI MANAJEMEN K3 TERHADAP KINERJA BIAYA \\ PELAKSANAAN PROYEK KONSTRUKSI \\ Yaser Arafat dan Retna Hapsari Kartadiputra}

meminimalisir kecelakaan para pekerjanya. Para pekerja merupakan salah satu Sumber Daya Manusia atau SDM terpenting bagi perusahaan konstruksi (Busyairi, dkk 2014: 114). SDM sangat diperlukan dalam penyelesaikan proyek konstruksi sehingga diperlukan perhatian khusus kepada SDM agar mereka dapat bekerja dengan produktif. Dengan menerapkan perencanaan K3 pada pekerjaan konstruksi maka dapat meningkatkan keselamatan dalam bekerja.

Upaya pemerintah untuk mencegah terjadinya kecelakaan kerja Sekarang ini sudah banyak peraturan-peraturan pemerintah baik dari Undang-undang sampai Keputusan Menteri yang mengatur tentang K3 ini. Kendati K3 merupakan unsur penting dalam pelaksanaan proyek konstruksi namun masih banyak perusahaan konstruksi yang tidak menerapkan unsur keselamatan dan kesehatan ini, padahal hal itu tidak bisa dihindarkan. Di Indonesia, mayoritas manajemen perusahaan konstruksi kurang mempersiapkan dan menyediakan ketentuan $\mathrm{K} 3$ di tempat kerjanya. Hal itu disebabkan karena masih menganggap K3 hanya sebagai biaya dan beban. Tak jarang, mereka pun berpandangan bahwa K3 hanya menguntungkan pekerja saja, pandangan keliru ini dinilai sebagai bentuk pengabaian K3 yang dilakukan perusahaan.

Hasil penelitian yang dilakukan Busyairi, dkk (2014: 123) membukikan jika sebesar 65,5 \% tingkat produktivitas kerja dipengaruhi oleh keselamatan kerja. Artinya semakin baik penerapan K3 dalam pelaksanaan proyek konstruksi maka akan semakin produktif pula para pekerjanya. Pekerja yang produktif maka akan semakin cepat perusahaan konstruksi dalam menyelesaikan proyeknya.

Dari hasil penelitian yang dilakukan Busyairi, dkk (2014) ini sebenarnya penerapan K3 bukanlah menjadi beban dalam pengelolaan biaya perusahaan-perusahaan jasa konstruksi, tetapi justru menjadi salah satu faktor pendorong para pekerja agar lebih produktif dalam bekerja. Todingan dkk (2015) menjelaskan bahwa kecelakaan kerja baik secara langsung ataupun tidak menyebabkan kerugian bagi perusahaan konstruksi. Perusahaan dapat mengalami kerugian seperti pekerjaan yang terlambat penyelesaiannya, produktivitas menurun, mahalnya biaya penyembuhan, serta bagi tenaga kerja yang mengalami kecelakaan akan mendapatkan penderitaan secara pribadi. Jadi penerapan K3 yang kurang baik sejatinya dapat menyebabkan kerugian bagi perusahaan konstruksi itu sendiri, sehingga walaupun manajemen K3 dapat meningkatkan kinerja biaya, namun memiliki dampak yang baik dalam penyelesaian proyek.

Kinerja secara sederhana dapat diartikan sebagai hasil kerja yang dapat dicapai sesuai dengan apa yang menjadi tanggungjawabnya dan dapat dibenarkan secara legat atau tidak melanggar hukum moral serta etika (Rivai \& Basri, 2004). Artinya dalam mencapai kinerja seseorang tidak hanya mementingkan tujuan namun juga harus memperhatikan hukum dan etika yang berlaku. Berkaitan dengan biaya biaya Tunggal (2014) menjelaskan bahwa biaya nilai (uang) yang dikeluarkan guna mendapatkan barang dan jasa. Jadi kinerja biaya adalah pencapaian perusahaan dalam mengeluarkan sejumlah nilai moneter untuk memperoleh barang dan jasa dalam kasus ini adalah pengorbanan nilai moneter pada penerapan $\mathrm{K} 3$.

Hasil penelitian yang dilakukan oleh Tondingan dkk (2015) membuktikan terdapat pengaruh positif yang signifikan antara penerapan K3 terhadap biaya pelaksanaan proyek konstruksi. Artinya penerapan sistem K3 dapat meningkatkan biaya dalam penyelesaian proyek konstruksi. Adanya persepsi bahwa penerapan manajemen K3 ini memberikan pengaruh yang tidak menguntungkan kepada perusahaan jasa konstruksi dalam melaksanakan pekerjaan atau proyek konstruksinya perlu dilakukan kajian lebih lanjut. Hal ini dikarenakan penerapan K3 memang disatu sisi meningkatkan biaya, namun disisi lain dapat mendorong para pekerja untuk bekerja lebih produktif dan dapat menekan biaya untuk pengobatan pada saat terjadi kecelakaan.

Dari permasalahan yang diangkat, penelitian ini akan membahas mengenai penerapan atau implementasi faktor-faktor sistem manajemen K3 terhadap kinerja biaya pekerjaan proyek konstruksi dan menganalisa seberapa besar pengaruhnya terhadap keberhasilan atau kinerja biaya dari 
perusahaan jasa konstruksi tersebut dalam melaksanakan proyek konstruksinya.

\section{METODE PENELITIAN}

Rancangan penelitian ini didasari oleh adanya ide atau gagasan akan perlunya perhatian terhadap faktor implementasi Sistem Manajemen Keselamatan dan Kesehatan Kerja (SMK3) yang memberi pengaruh terhadap kinerja biaya pelaksanaan proyek. Adanya identifikasi mengenai pengaruh faktor-faktor implementasi SMK3 terhadap kinerja biaya tersebut, maka diharapkan pada pelaksanaan proyek diketahui tingkatan pengaruh faktorfaktor implementasi sistem manajemen K3 terhadap kinerja biaya pelaksanaan proyeknya, dan hubungan antara keduanya.

Populasi utama yang menjadi objek penelitian adalah perusahaan konstruksi yang ada di wilayah Kalimantan Kalsel dengan kualifikasi besar menengah kecil dan telah berpengalaman dalam menerapkan K3. Dari kriteria ini maka populasi penelitian adalah 10 perusahaan konstruksi. Adapun yang dijadikan responden dalam penelitian adalah para pemegang jabatan tertinggi (direktur/manager) sampai tingkatan jabatan dibawahnya yang masih memiliki peran dalam sistem manajemen K3 perusahaan. Berdasarkan hal ini maka sampel pada penelitian ini sebanyak 36 responden

Variabel dalam penelitian terdiri dari variabel independen dan dependen. Ada empat variabel independen dalam penelitian ini yaitu variabel Perencanaan, Pelaksanaan, Evaluasi dan Tindak lanjut (X). Adapun variabel dependennya adalah variabel Kinerja Biaya Proyek (Y).

Prosedur pengumpulan data yaitu dengan melakukan wawancara ke tiap responden dan membagikan kuisioner berupa pertanyaan-pertanyaan sehubungan dengan data-data implementasi SMK3 terhadap kinerja biaya proyeknya. Semua hasil pengisian dari quisioner tadi kemudian dianalisa berdasarkan hasil skala pengukuran yang didapat, sehingga didapatkan pengaruh hubungan di antara keduanya. Berdasarkan hasil evaluasi dan pengukuran pada tiap-tiap data tadi, didapatkan kesimpulan berupa tingkat pengaruh dari penerapan sistem manajemen K3 terhadap kinerja biaya pelaksanaan proyek.

Instrumen yang digunakan adalah angket yang berisi pertanyaan yang diisi oleh responden. Pengembangan instrumen berdasar pada teori yang telah disusun dalam bab sebelumnya. Instrumen ini digunakan untuk mengetahui pengaruh anatara variabel independen terhadap variabel dependen. Instrumen yang digunakan dalam penelitian ini adalah berupa kuisioner yang berisi pertanyaan-pertanyaan tertutup. Bentuk dari instrumen penelitian ini seperti terlihat pada Tabel 1.

Tabel 1. Instrumen penelitian

\begin{tabular}{|c|c|c|}
\hline $\begin{array}{c}\text { Faktor } \\
\text { Manajemen }\end{array}$ & Variabel & Indikator \\
\hline \multirow[t]{3}{*}{ Perencanaan } & 1. Kebijakan & $\begin{array}{l}\text { 1. Pemahaman peraturan perundangan dan persyaratan lainnya } \\
\text { 2. Kepemimpinan } \\
\text { 3. Pembentukan organisasi K3 } \\
\text { 4. Penetapan personil yang bertanggungjawab } \\
\text { 5. Membuat perencanaan K3 yang terkordinasi }\end{array}$ \\
\hline & 2. Komitmen & $\begin{array}{l}\text { 6. Pemberlakukan kebijakan secara tertulis sebagai landasan } \\
\text { operasional bagi semua unsur di perusahaan } \\
\text { 7. Komitmen menjamin K3 tenaga kerja dan orang lain (tamu, } \\
\text { pengunjung, pemasok, dan kontraktor) di tempat kerja } \\
\text { 8. Komitmen melakukan perbaikan berkelanjutan terhadap } \\
\text { sistem manajemen dan kinerja K3 }\end{array}$ \\
\hline & 3. Perencanaan program K3 & $\begin{array}{l}\text { 9. Perencaan awal dan perencanaan kegiatan yang berlangsung } \\
\text { 10. Perencaan identifikasi bahaya dan risiko } \\
\text { 11. Adanya kerangka kerja untuk penetapan tujuan dan sasaran } \\
\text { kebijakan K3 } \\
\text { 12. Penjelasan pemahaman peraturan perundangan dan } \\
\text { persyaratan lainnya } \\
\text { 13. Perencanaan indikator pencapaian atau kinerja K3 perusahaan }\end{array}$ \\
\hline
\end{tabular}




\section{ANALISIS FAKTOR IMPLEMENTASI MANAJEMEN K3 TERHADAP KINERJA BIAYA}

PELAKSANAAN PROYEK KONSTRUKSI

Yaser Arafat dan Retna Hapsari Kartadiputra

Tabel 1 (lanjutan)

\begin{tabular}{c} 
Faktor \\
Manajemen \\
\hline \hline
\end{tabular}

Pelaksanaan 4. Jaminan Kemampuan
14. Ketersedian SDM yang berkualifikasi

15. Ketersedian sarana dan prasarana yang memadai sesuai K3

16. Ketersedian dana yang memadai sesuai SMK3

17. Integrasi sistem manajemen $\mathrm{K} 3$ dalam sistem manajemen perusahaan

18. Partisipasi dan konsultasi seluruh personel mengenai penerapan $\mathrm{k} 3$ di tempat kerja

19. Motivasi dan kesadaran

20. Pelatihan dan kompetensi kerja bagi tenaga kerja

21. Tanggungjawab pimpinan dalam memastikan bahwa SMK3 telah diterapkan

22. Tanggungjawab pengurus dalam mengenali kemampuan tenaga kerja

23. Memberikan reaksi secara cepat dan tepat terhadap kondisi yang menyimpang

5. Kegiatan Pendukung 24. Kegiatan komunikasi mengenai informasi K3

25. Pelaporan informasi K3

26. Pendokumentasian sistem manajemen K3

27. Pengendalian dokumen

28. Pencatatan dan manajemen informasi

6. Identifikasi sumber 29. Pengumpulan informasi dan data berkaitan dengan bahaya K3 bahaya, penilaian dan 30 . Identifikasi sumber bahaya pengendalian risiko 31 . Penilaian risiko dan penyakit

32. Penilaian kompetensi personel K3

33. Pengendalian risiko kecelakaan dan penyakit akibat kerja

34. Perencanaan dan rekayasa pengendalian risiko

35. pengendalian administratif

36. Tinjauan ulang kontrak

37. Identifikasi pembelian dalam memenuhi persyaratan K3

38. Prosedur menghadapi keadaan darurat dan bencana

39. Prosedur menghadapi insiden

40. Prosedur rencana pemulihan keadaan darurat

Evaluasi 7. Pemantauan

41. Memantau pemenuhan peraturan perundang-undangan dan persyaratan lainnya berkaitan dengan penerapan $\mathrm{K} 3$ di tempat kerja

42. Pemantauan kejadian-kejadian kecelakaan kerja dan penyakit akibat kerja

43. Pemantauan efektifitas pengendalian

8. Evaluasi 44. Penetapan dan pemeliharaan prosedur inspeksi dan pengujian

45. Evalusai penerapan SMK3 perusahaan

46. Evaluasi kefektifan pengendalian operasi K3

47. Pelaksanaan audit SMK3

9. Perbaikan
pencegahan

dan 48. Pengujian peralatan dan mesin sebelum dioperasikan untuk produksi

49. Pemerikasaan penyimpangan bahan-bahan, terutama yang mengandung bahaya, tidak melebihi batas maksimum yang ditentukan.

\begin{tabular}{lcr} 
Tindak & 10. Tinjauan Ualang \\
panjut & daningkatan & $\begin{array}{l}50 \text {. Tinjauan ulang SMK3 secara berkala } \\
\text { 51. Peningkatan pelaksanaan SMK3 secara berkesinambungan }\end{array}$ \\
\hline
\end{tabular}

Sebelum data digunakan untuk mengumpulkan data terlebih dahulu kuesioner diuji tingkat reliabelitas dan validitasnya. Pengujian reliabilitas menunjukkan pada tingkat kemantapan atau konsistensi suatu alat ukur (kuesioner). Uji relibilitas dilakukan secara bersama-sama terhadap seluruh butir pertanyaan. Jika nilai Alpha > dari 0,06 maka butir pertanyaan tersebut reliabel (Sujarweni, 2008). Sementara itu valid berarti instrument yang dipilih dapat digunakan untuk mengukur apa yang seharusnya diukur (Sugiyono, 2002) 
untuk menentukan suatu validitas adalah dengan mengkonsultasikan tabel product moment. Jika $\mathrm{r}$ hasil $>$ dari $\mathrm{r}$ tabel maka dikatakan valid dan jika $r$ hasil < dari $r$ tabel maka dikatakan tidak valid. Uji coba instrumen menggunakan product moment person.

Analisis data dengan menggunakan statistik deskriptif yaitu data penelitian ini dibuat kategori guna memperoleh keterangan tentang kelompok subjek pada variabel yang diteliti. Tujuan dari Analisis angka indeks ini adalah untuk mengetahui persepsi responden secara umum tentang variabel yang diteliti. Untuk menggambarkan persepsi responden akan pertanyaan yang diajukan itu, maka dilakukan analisis indeks. Analisis indeks dilakukan dengan menggunakan rumus berikut ini: (Ferdinand, 2011)

Keterangan :

$\mathrm{P}=$ Presentase

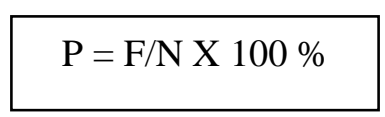

$\mathrm{F}=$ Frekuensi atau banyaknya jawaban

$\mathrm{N}=$ Jumlah Responden
Selain analisis deskriptif, data juga dianalisis dengan analisa korelasi. Penggunaan analisis korelasi untuk menjawab pertanayaan bagaiamana korelasi implementasi faktor K3 terhadap kinerja biaya pelaksanaan proyek konstruksi. Uji korelasi yang digunakan adalah uji Korelasi Pearson's Product Moment. Menurut Akdon dan Riduwan (2005) korelasi Pearson's Product Moment digunakan untuk mengetahui derajat hubungan antara variabel penelitian. Teknik analisis korelasi Pearson's Product Moment termasuk teknik statistik parametrik yang menggunakan data interval dan ratio dengan persyaratan (Akdon dan Riduwan, 2005). Korelasi Pearson's Product Moment dilambangkan (r) dengan ketentuan nilai $\mathrm{r}$ tidak lebih dari harga $(-1 \leq \mathrm{r} \leq+1)$. Apabila nilai $r=-1$ artinya korelasinya negatif sempurna; $r=0$ artinya tidak ada korelasi; dan $\mathrm{r}+1$ berarti korelasinya sangat kuat. Sedangkan arti harga $r$ akan dikonsultasikan dengan dengan tabel interpreasti nilai $r$ seperti terlihat pada Tabel 2 .

Tabel 2. Interpretasi Nilai $r$

\begin{tabular}{cc}
\hline Interval Koefisien & Tingkat Korelasi \\
\hline $0,80-1,000$ & Sangat Kuat \\
$0,60-0,799$ & Kuat \\
$0,40-0,599$ & Cukup Kuat \\
$0,20-0,399$ & Rendah \\
$0,00-0,199$ & Sangat Rendah \\
\hline
\end{tabular}

Sumber: Akdon dan Riduwan (2005)

3. HASIL DAN PEMBAHASAN

\subsection{Pengaruh Implementasi Faktor K3 Terhadap Kinerja Biaya Pelaksanaan Proyek Konstruksi}

Dari hasil analisis indeks pada faktor
Perencanaan diperoleh hasil jika variabel Kebijakan merupakan variabel yang paling besar dalam mempengaruhi kinerja biaya pelaksanaan proyek konstruksi. Hasil selengkapnya dapat dilihat pada Tabel 3.

Tabel 3. Pengaruh Implementasi Faktor Perencaan K3

\begin{tabular}{cccl}
\hline Variabel & Indikator & Indeks & \multicolumn{1}{c}{ Keterangan } \\
\hline \multirow{3}{*}{ Kebijakan } & X2 & 3,97 & Lebih Berpengaruh \\
& X4 & 3,92 & Lebih Berpengaruh \\
& X5 & 4,00 & Lebih Berpengaruh \\
\hline \multirow{2}{*}{ Komitmen } & X6 & 3,19 & Berpengaruh \\
& X8 & 3,53 & Lebih Berpengaruh \\
\hline \multirow{2}{*}{ Perencanaan } & X9 & 3,44 & Berpengaruh \\
& X10 & 3,97 & Lebih Berpengaruh \\
& X11 & 3,42 & Berpengaruh \\
& X13 & 3,17 & Berpengaruh \\
& Rata-rata & 3,62 & Lebih Berpengaruh \\
\hline
\end{tabular}




\section{ANALISIS FAKTOR IMPLEMENTASI MANAJEMEN K3 TERHADAP KINERJA BIAYA \\ PELAKSANAAN PROYEK KONSTRUKSI \\ Yaser Arafat dan Retna Hapsari Kartadiputra}

Berdasarkan Tabel di atas dapat diketahui bahwa indikator X5 (membuat perencanaan K3 yang terkordinasi) pada variabel kebijakan merupakan indikator yang dianggap paling mempengaruhi kinerja biaya pelaksanaan proyek konstruksi karena memiliki indeks terbesar yaitu 4,00. Hal ini menunjukkan bahwa perencanaan $\mathrm{K} 3$ menurut para responden merupakan faktor yang paling membutuhkan biaya yang besar. Sementara itu variabel perencanaan tepatnya indikator X13 (perencanaan indikator pencapaian atau kinerja K3 perusahaan) merupakan indikator yang tidak membutuhkan biaya besar dalam pelaksanaan proyek.

Dari hasil analisis indeks pada faktor Pelaksanaan diperoleh hasil jika variabel identifikasi sumber bahaya, penilaian dan pengendalian menjadi variabel yang paling besar dalam mempengaruhi kinerja biaya pelaksanaan proyek konstruksi. Hasil selengkapnya adalah sebagai berikut:

Tabel 4. Pengaruh Implementasi Faktor Pelaksanaan K3

\begin{tabular}{cccl}
\hline Variabel & Indikator & Indeks & \multicolumn{1}{c}{ Keterangan } \\
\hline \multirow{2}{*}{ Jaminan Kemampuan } & X17 & 3,50 & Berpengaruh \\
& X18 & 3,31 & Berpengaruh \\
\hline \multirow{3}{*}{ Kegiatan Pendukung } & X25 & 3,42 & Lebih Berpengaruh \\
& X26 & 3,39 & Berpengaruh \\
& X27 & 3,39 & Berpengaruh \\
\hline Identifikasi sumber bahaya, & X28 & 3,39 & Berpengaruh \\
penilaian dan pengendalian & X35 & 3,47 & Berpengaruh \\
risiko & X36 & 3,50 & Lebih Berpengaruh \\
& X37 & 3,67 & Lebih Berpengaruh \\
& X38 & 3,86 & Lebih Berpengaruh \\
& X39 & 3,78 & Lebih Berpengaruh \\
& X40 & 3,83 & Lebih Berpengaruh \\
& Rata-rata & 3,55 & Lebih Berpengaruh \\
\hline
\end{tabular}

Berdasar Tabel di atas diketahui jika indikator X38 (prosedur menghadapai keadaan darurat dan bencana) merupakan indikator yang paling berpengaruh terhadap kinerja biaya dengan indeks 3,86 . Hal ini menurut para responden indikator X38 merupakan faktor yang memiliki pengaruh besar terhadap kinerja biaya proyek. Para responden menganggap jika prosedur menghadapi keadaan darurat dan bencana merupakan kegiatan yang dapat meningkatkan jumlah biaya dalam penyelesaian proyek konstruksi. Sementara itu indikator X18 (partisipasi dan konsultasi seluruh personel mengenai penerapan K3 ditempat kerja) menurut responden adalah faktor yang paling sedikit dalam mempengaruhi kinerja biaya proyek konstruksi. Memang secara logika indikator ini tidak memerlukan pembiayaan besar karena sifatnya adalah on the job, artinya perusahaan tidak mengeluarkan biaya khusus untuk faktor ini sehingga tidak meningkatkan biaya.

Dari hasil analisis indeks pada faktor Evaluasi diperoleh hasil jika variabel evaluasi merupakan variabel yang paling besar dalam mempengaruhi kinerja biaya pelaksanaan proyek konstruksi. Hasil selengkapnya dapat dilihat pada Tabel 5.

Tabel 5. Pengaruh Implementasi Faktor Evaluasi K3

\begin{tabular}{cccl}
\hline Variabel & Indikator & Indeks & \multicolumn{1}{c}{ Keterangan } \\
\hline \multirow{4}{*}{ Pemantauan } & X41 & 3,14 & Berpengaruh \\
& X42 & 3,08 & Berpengaruh \\
& X43 & 3,17 & Berpengaruh \\
\hline \multirow{4}{*}{ Evaluasi } & X44 & 3,47 & Berpengaruh \\
& X45 & 3,47 & Berpengaruh \\
& X46 & 3,58 & Lebih Berpengaruh \\
& X47 & 3,47 & Berpengaruh \\
\hline
\end{tabular}


Dari Tabel di atas diketahui bahwa indikator X46 (evaluasi keefektifan pengendalian operasi K3) merupakan indikator yang paling berpengaruh pada kinerja biaya K3 dalam faktor evaluasi dengan nilai indeks sebesar 3,58. Hal ini menunjukkan bahwa perusahaan aktif dalam melakukan evaluasi terhadap pelaksaan K3 di perusahaannya sehingga membutuhkan biaya tambahan untuk melakukannya. Sementara itu indikator X42 (Pemantauan kejadian-kejadian kecelakaan kerja dan penyakit akibat kerja) merupakan indikator dalam faktor evaluasi yang paling rendah dalam mempengaruhi kinerja biaya proyek konstruksi. Hal ini menunjukkan jika memang kegiatan ini bersifat rutinitas yang tidak membutuhkan anggaran tambahan.

\subsection{Tingkat Pengaruh Implementasi Faktor K3 Terhadap Kinerja Biaya dalam Pelaksanaan Konstruksi.}

Dari hasil analisis indeks membuktikan bahwa implementasi faktor perencanaan K3 secara rata-rata memiliki indeks 3,62 (lebih berpengaruh). Artinya implementasi faktor perencanaan K3 memiliki pengaruh besar terhadap kinerja biaya pelaksanaan proyek konstruksi. Pada penelitian ini, faktor perencanaan memiliki tiga variabel yaitu kebijakan, komitmen, dan perencaan program K3. Ketiga variabel ini memang membutuhkan biaya yang besar seperti penetapan personil yang bertanggungjawab sehingga perusahaan harus mengeluarkan anggaran tambahan untuk menggaji para personil yang bertanggungjawab dalam pelaksanaan K3.

Dari hasil analisis indeks selanjutnya membuktikan bahwa implementasi faktor pelaksanaan K3 secara rata-rata memiliki indeks 3,55 (lebih berpengaruh). Artinya implementasi faktor pelaksanaan $\mathrm{K} 3$ memiliki pengaruh besar terhadap kinerja biaya pelaksanaan proyek konstruksi. Faktor pelaksanaan dalam penelitian ini terdiri dari variabel jaminan kemampuan, kegiatan pendukung, dan identifikasi sumber bahaya, penilaian dan pengendalian risiko. Pada faktor pelaksanaan perusahaan harus mengeluarkan biaya untuk menyediakan sarana prasarana yang memadai dalam SMK3. Selain itu perusahaan juga harus menyelenggarakan pelatihan dalam menghadapi insiden, menghadapi keadaan darurat dan bencana serta lain sebagainya. Faktor pelaksanaan K3 oleh para responden merupakan faktor yang berkaitan dengan pertambahan biaya dalam penyelesaian proyek konstruksi.

Dari hasil analisis indeks selanjutnya membuktikan bahwa implementasi faktor evaluasi K3 secara rata-rata memiliki indeks 3,34 (berpengaruh). Artinya implementasi faktor evaluasi K3 memiliki pengaruh lebih kecil terhadap kinerja biaya pelaksanaan proyek konstruksi dibandingkan dengan faktor perencanaan dan pelaksanaan. Pada penelitian ini diketahui jika faktor evaluasi K3 merupakan faktor yang berpenaruh paling kecil bila dibandingkan dengan kedua faktor dalam implementasi K3. Kecilnya pengaruh faktor evaluasi K3 terhadap kinerja biaya proyek disebabkan memang pada evaluasi ini perusahaan tidak mengeluarkan banyak biaya. Hal ini disebabkan pada faktor evaluasi K3 perusahaan hanya melakukan pemeliharaan, pemantauan dan lain sebagainya, sehingga difat dari kegiatan evaluasi hanya bersifat evaluasi atau memelihara saja.

\subsection{Hubungan Faktor-faktor K3 Terhadap Kinerja Biaya Pelaksanaan Konstruksi}

Setelah melalui berbagai pengujian pada akhirnya faktor-faktor K3 dalam penelitian ini ditemukan 29 indikator. Dari 29 indikator tersebut kemudian dilakukan analisis korelasi terhadap beberapa komponen biaya proyek seperti asuransi, fasilitas kesehatan dan lain sebagainya. Hasil korelasi pada sub bab ini hanya ditampilkan indikator yang memiliki korelasi kuat dan cukup kuat. Hasil uji korelasi ini dapat dilihat pada Tabel 6 s.d Tabel 11.

Tabel 6. Indikator yang Memiliki Korelasi terhadap Biaya Asuransi

\begin{tabular}{lccc}
\hline Indikator & Sig & Koefisien Korelasi & Keterangan \\
\hline X28 & 0,009 & 0,428 & Cukup Kuat \\
X35 & 0,011 & 0,401 & Cukup Kuat \\
X41 & 0,000 & 0,656 & Kuat \\
\hline
\end{tabular}




\section{ANALISIS FAKTOR IMPLEMENTASI MANAJEMEN K3 TERHADAP KINERJA BIAYA \\ PELAKSANAAN PROYEK KONSTRUKSI \\ Yaser Arafat dan Retna Hapsari Kartadiputra}

Hasil analisis korelasi di atas dapat diketahui bahwa indikator X41 (memantau pemenuhan peraturan perundang - undangan dan persyaratan lainnya berkaitan dengan penerapan K3 di tempat kerja) merupakan indikator yang memiliki korelasi kuat terhadap biaya asuransi. Artinya semakin perusahaan memenuhi peraturan perundanganundangan maka akan semakin besar pula perusahaan mengeluarkan biaya asuransi. Kepatuhan perusahaan terhadap peraturan perundangan-undangan maka perusahaan akan mengeluarkan biaya untuk asuransi bagi para pekerjanya.

Tabel 7. Indikator yang Memiliki Korelasi terhadap Peralatan Keamanan

\begin{tabular}{lccl}
\hline \multicolumn{1}{c}{ Indikator } & Sig & Koefisien Korelasi & \multicolumn{1}{c}{ Keterangan } \\
\hline X2 & 0,005 & 0,432 & Cukup Kuat \\
X28 & 0,009 & 0,405 & Cukup Kuat \\
X39 & 0,001 & 0,485 & Cukup Kuat \\
X36 & 0,000 & 0,769 & Kuat \\
\hline
\end{tabular}

Dari uji korelasi di atas dihasilkan bahwa indikator X36 (tinjauan ulang kontrak) merupakan indikator yang berhubungan kuat dengan biaya proyek dalam hal peralatan keamanan. Jadi semakin baik perusahaan dalam meninjau ulang kontrak maka perusahaan akan menguluarkan banyak biaya untuk pembelian peralatan keamanan. Perusahaan memiliki kepentingan untuk menyediakan perlatan keamanaan yang memadai bagi para pekerja karena semakin baik peralatan keamanan maka akan semikan terjamin keselamatan para pekerjanya.

Tabel 8. Indikator yang Memiliki Korelasi terhadap Fasilitas Kesehatan

\begin{tabular}{cccc}
\hline Indikator & Sig & Koefisien Korelasi & Keterangan \\
\hline X5 & 0,001 & 0,507 & Cukup Kuat \\
X6 & 0,002 & 0,468 & Cukup Kuat \\
X9 & 0,001 & 0,529 & Cukup Kuat \\
X35 & 0,002 & 0,452 & Cukup Kuat \\
X43 & 0,000 & 0,799 & Kuat \\
X45 & 0,001 & 0,478 & Cukup Kuat \\
X47 & 0,007 & 0,413 & Cukup Kuat \\
\hline
\end{tabular}

Dari data di atas dapat diketahui bahwa indikator X43 ( pemantauan efektifitas pengendalian) merupakan indikator yang memiliki korelasi kuat dengan fasilitas kesehatan. Jadi semikian baik perusahaan melakukan pemanatauan terhadap pengendalian K3 maka akan semakin baik pula fasilitas kesehatan perusahaan. Perusahaan yang memiliki fasilitas kesehatan yang baik maka akan semakin mudah pula dalam pelaksanaan K3 di perusahaan.

Tabel 9. Indikator yang Memiliki Korelasi terhadap Bangunan-bangunan Pengamanan dan Rambu-Rambu

\begin{tabular}{cccc}
\hline Indikator & Sig & Koefisien Korelasi & Keterangan \\
\hline X44 & 0,000 & 0,822 & Sangat Kuat \\
X47 & 0,008 & 0,407 & Cukup Kuat \\
\hline
\end{tabular}

Data di atas menunjukkan jika indikator X44 (penetapan dan pemeliharaan prosedur inspeksi dan pengujian) merupakan indikator yang berhubungan kuat dengan biaya bangunan-bangunan pengamanan dan ramburambu. Jadi semakin sering perusahaan melakukan pengujian, ispeksi dan pemiliharaan maka akan semakin sering perusahaan melakukan perbaikan bangunanbangunan pengamanan dan rambu-rambu. Hal ini dikarenakan dari hasil pengujian, ispeksi dan pemiliharaan perusahaan akan semakin mengetahui apa yang masih kurang dalam pelaksanaan $\mathrm{K} 3$. 
Tabel 10. Indikator yang Memiliki Korelasi terhadap Biaya Pengawasan Terhadap Penerapan Safety

\begin{tabular}{lccc}
\hline \multicolumn{1}{c}{ Indikator } & Sig & Koefisien Korelasi & Keterangan \\
\hline X9 & 0,005 & 0,429 & Cukup Kuat \\
X35 & 0,002 & 0,452 & Cukup Kuat \\
X43 & 0,004 & 0,433 & Cukup Kuat \\
X45 & 0,000 & 0,806 & Sangat Kuat \\
\hline
\end{tabular}

Data di atas menunjukkan bahwa indikator X45 (evaluasi penerapan sistem manajemen K3 perusahaan) merupakan indikator yang berkorelasi sangat kuat terhadap biaya pengawasan terhadap penerapan safety. Hal ini menunjukkan jika adanya evaluasi sistem manajemen K3 perusahaan maka akan semakin meningkatkan biaya pengawasan terhadap penerapan safety, karena perusahaan akan memiliki dasar yang kuat dalam memberlakukan manajemen K3. Melalui evaluasi penerapan sistem manajemen
K3 perusahaan dapat mengetahui kebijakan mana yang tepat dalam pengawasan terhadap penerapan safety.

Indikator yang memiliki korelasi terhadap biaya-biaya kecelakaan yang terjadi dalam penelitian ini hannya indikator X46 (evaluasi keefektifan pengendalian operasi K3) yang berkorelasi kuat terhadap biaya-biaya kecelakaan yang terjadi. Jadi semakian baik perusahaan dalam melakukan evaluasi keefektifan pengendalian operasi K3 akan meningkatkan biaya-biaya kecelakaan yang terjadi.

Tabel 11. Indikator yang Memiliki Korelasi terhadap Biaya lain yang Berkaitan dengan Sistem Keamanan Kerja

\begin{tabular}{lccc}
\multicolumn{1}{c}{ Indikator } & Sig & Koefisien Korelasi & Keterangan \\
\hline X9 & 0,006 & 0,431 & Cukup Kuat \\
X43 & 0,004 & 0,440 & Cukup Kuat \\
X44 & 0,002 & 0,483 & Cukup Kuat \\
X47 & 0,000 & 0,812 & Sangat Kuat \\
\hline
\end{tabular}

Dari analisis korelasi menunjukkan bahwa indikator X47 (pelaksanaan audit sistem manajemen K3) merupakan indikator yang berkorelasi sangat kuat terhadap biaya lain yang berkaitan dengan sistem keamanan kerja. Artinya semakin perusahaan melakukan audit sistem manajemen K3 dengan baik maka perusahaan akan mengeluarkan banyak biaya untuk meningkatkan sistem keamanan kerja. Pelaksaan audit sistem manajemen K3 yang baik maka perusahaan akan mengetahui jika sistem keamanan kerja pada perusahaannya belum cukup baik, sehingga perlu meningkatkan sistem keamanan kerja. Peningkatkan sistem keamanan kerja pada akhirnya dapat meningkatkan biaya kinerja penyelesaian proyek konstruksi.

\section{KESIMPULAN}

Kesimpulan dari penelitian ini adalah sebagai berikut:

1. Implementasi faktor K3 terbukti berpengaruh terhadap kinerja biaya pelaksanaan proyek konstruksi dengan besar indeks 3,50 (Lebih Berpengaruh).

Tingkat pengaruh implementasi faktor perencanaan K3 memiliki indeks 3,62 (lebih berpengaruh). Faktor pelaksanaan K3 secara rata-rata memiliki indeks 3,55 (lebih berpengaruh). Sedangkan faktor evaluasi K3 secara rata-rata memiliki indeks 3,34 (berpengaruh).

2. Faktor-faktor implementasi K3 memiliki hubungan yang cukup kuat dengan kinerja biaya dengan besar korelasi $(5,30)$. 


\section{ANALISIS FAKTOR IMPLEMENTASI MANAJEMEN K3 TERHADAP KINERJA BIAYA \\ PELAKSANAAN PROYEK KONSTRUKSI \\ Yaser Arafat dan Retna Hapsari Kartadiputra}

\section{DAFTAR RUJUKAN}

Akdon dan Riduwan. 2005. Rumus dan Data dalam Aplikasi Statistika. Bandung: Alfabeta.

Asiyanto. 2005.Construction Project Cost Management. Jakarta: PT. Pradnya Paramita

Busyairi, M. dkk. 2015. "Pengaruh Keselamatan Kerja dan Kesehatan Kerja Terhadap Produktivitas Kerja Karyawan", Jurnal Ilmiah Teknik Industri, Vol. 13, No. 2, Des 2014

Dipohusodo, I.1996. Manajemen Proyek \& Konstruksi. Yogyakarta: Kanisius.

Donnelly, dkk. 1994. Fundamental of Management. Texas: Business Publication.

Ferdinand, A. 2011. Structural Equation Modelling Dalam Penelitian Manajemen. Semarang: BP Undip

Kurniawan, C. 2015. "Angka Kecelakaan Pekerja Konstruksi 31,9 Persen”. Diakses dari http://www.republika.co.id/berita/nasional /umum/15/06/29/nqplkta-angkakecelakaan-pekerja-konstruksi-319persen. 11/8/2017 (diakses 11 Agustus 2017)
Peraturan Menteri (Permen) PU No.9 tahun 2008 tentangPedoman Sistem Manajemen Kesehatan \& Keselamatan Kerja (SMK3) Konstruksi

Peraturan Menteri Tenaga Kerja R.I.. No. Per.05/MEN/1996 tentang Sistem Manajemen Keselamatan dan Kesehatan Kerja

Rivai, Muhammad dan Basri, A. 2004. Manajemen Kinerja. Bandung: Remaja Rosdakarya

Sugiyono. 2002. Metode Penelitian Administrasi. Bandung: Alfabeta.

Todingan, A.A. 2015. "Pengaruh Penerapan Sistem Manajemen Keselamatan dan Kesehatan Kerja Terhadap Biaya Pelaksanaan Proyek Konstruksi (Studi Kasus: Manado Town Square 3)", Jurnal Sipil Statik

Tunggal, A.W. 2014. Pengetahuan Dasar Auditing. Jakarta: Harvarindo 